\title{
ENTRE FIOS: \\ LINIANE HAAG BRUM E MARIA PILLA \\ ENTRE HILOS: \\ LINIANE HAAG BRUM Y MARIA PILLA
}

DOI 10.20873/uft2179-3948.2021v12n1p86-101

\section{Hibrahima Nelia Oliveira ${ }^{1}$ Natália Moreira Viana ${ }^{2}$}

Resumo: Este artigo visa apresentar as obras literárias de Liniane Haag Brum intitulada Antes do Passado: o silêncio que vem do Araguaia (2010) e de Maria Pilla intitulada Volto Semana que vem (2015). Ambas as obras possuem como base o período ditatorial, em Antes do Passado, em foco a Guerrilha do Araguaia e em Volto Semana que vem, as ditaduras do Brasil e da Argentina. Tanto Brum, quanto Liniane em seus testemunhos mostram seus traumas ocasionados pela violência de Estado, e através de suas memórias viabilizam um arquivo da ditadura.

Palavras - chave: ditadura; testemunho; arquivo; memória.

Resumen: Este artículo tiene como objetivo presentar las obras literarias de Liniane Haag Brum titulada Antes do Passado: o silêncio que vem do Araguaia (2010) y de Maria Pilla titulada Volto Semana que vem (2015). Las dos se basan en el periodo dictatorial, en Antes do Passado, el eje eres la Guerrilla del Araguaia y en Volto Semana que vem, las dictaduras del Brasil y Argentina. Tanto Brum como Pilla en sus testimonios muestran sus traumas provocados por la violencia del Estado, y por medio de sus memorias hacen posible un archivo de la dictadura.

Palabras claves: dictadura; testimonio; archivo; memoria.

\section{Introdução}

Este artigo faz referência ao mito de Ariadne. No mito, Teseu obteve ajuda de Ariadne que lhe concedeu um fio de lã para que fosse ao centro do labirinto construído por Dédalo, e encontrasse a saída sem se perder e sem ser devorado pelo Minotauro. No caso desta leitura, o fio de Ariadne simboliza o fio condutor entre as obras Antes do Passado: o silêncio que vem do Araguaia de Liniane Haag Brum publicado em 2010 e Volto semana que vem, de Maria Pilla,

\footnotetext{
${ }^{1}$ Mestra em História da Literatura, doutoranda em História da Literatura na Universidade Federal do Rio Grande (FURG). hibrahimano@gmail.com

${ }^{2}$ Mestra em História da Literatura, doutoranda em História da Literatura na Universidade Federal do Rio Grande (FURG). natalia.viana.84@gmail.com
} 
em 2015. Teseu simboliza as narradoras e o Minotauro, a tortura, que foi vivida de formas distintas: no caso de Liniane Brum através da herança do período ditatorial com a perda de seu tio e padrinho Cilon Cunha Brum, e de Maria Pilla, diretamente enquanto militante contra o regime ditatorial. Ambas chegaram perto de serem devoradas pelo Minotauro, mas através do fio de Ariadne, assim como Teseu, conseguiram se salvar. O fio, no caso das obras em análise, é a escrita, pois através dela as autoras conseguiram a redenção no labirinto do trauma.

Pela escrita, as narradoras contaram suas histórias de maneira afetiva, e a afetividade é outro ponto que entrecruza as obras de Brum e Pilla. Em Brum, a afetividade se dá por reconstruir o trajeto de seu tio e padrinho Cilon, enquanto para Pilla, acontece através de suas memórias de infância, dos pais e da juventude com os amigos. Nas duas obras perpassam a história da ditadura através de suas vivências pessoais, da passagem do político pela esfera pessoal.

Da tessitura das obras com o período ditatorial, resulta um conceito que nos últimos anos vem ganhando espaço nos estudos literários, o testemunho. Tanto Brum quanto Pilla apresentam em suas escritas marcas de teor testemunhal (SILVA, 2003), conforme explanação a ser realizada no presente estudo.

Ao ler e analisar as obras de Brum e Pilla, observamos que a escrita dessas autoras nos pertencem, pois contam suas vivências de tempos coercitivos do passado, e de "sua incrível capacidade de não passar" (TELES; SAFATLE, 2010, p.9), e da herança deixada no presente. Sendo assim, segundo a pesquisadora Eurídice Figueiredo (2017), a literatura também desempenha função de arquivo da ditadura, que suscita a memória dos sobreviventes e a pósmemória dos herdeiros, da nossa geração, a "geração seguinte” (HIRSCH, 2014).

\section{Labirinto do trauma}

Em 1964 instaurou-se no Brasil a ditadura militar que perdurou por 21 anos. Este período foi marcado pelo cerceamento da liberdade e pelo uso da tortura aos considerados opositores políticos. Deste período coube ao Brasil o pioneirismo da ditadura no Cone Sul, e sucessivamente Argentina, Chile e Uruguai foram tomados pelo regime ditatorial, e logo tal modelo repressor alastrou-se pela América Latina, com exceção de México e Venezuela.

Em 1979 foi sancionada a Lei da Anistia, ato jurídico em que crimes políticos foram perdoados. Retomado, assim, o caminho para a democracia, diferente dos demais países sulamericanos, o Brasil foi o único que não puniu seus torturadores (a Lei da Anistia beneficiava, tanto vítimas do golpe militar, como os militares responsáveis por torturas, mortes e 
desaparecimentos de opositores do regime), o que até hoje reflete em nossa sociedade e que oportunizou e oportuniza o estado violento e a impunidade dos tempos atuais. No livro $O$ que resta da Ditadura: A exceção brasileira, logo na apresentação, seus organizadores Edson Teles e Vladimir Safatle pontuam,

\begin{abstract}
Quando estudos demonstram que, ao contrário do que aconteceu em outros países da América Latina, as práticas de tortura em prisões brasileiras aumentaram em relação aos casos de tortura na ditadura militar; quando vemos o Brasil como único país sulamericano onde torturadores nunca foram julgados, onde não houve justiça de transição, onde o Exército não fez um mea culpa de seus pendores golpistas; quando ouvimos sistematicamente oficiais na ativa e na reserva fazerem elogios inacreditáveis à ditadura militar; quando lembramos que 25 anos depois do fim da ditadura convivemos com o ocultamento de cadáveres daqueles que morreram nas mãos das Forças Armadas; então começamos a ver, de maneira um pouco mais clara, o que significa exatamente 'violência'. Pois nenhuma palavra melhor que 'violência' descreve esta maneira que tem o passado ditatorial de permanecer como um fantasma a assombrar e contaminar o presente. (...) (TELES; SAFATLE, 2010, p.10, grifos dos autores).
\end{abstract}

A ditadura brasileira, passados mais de 50 anos de seu encerramento oficial, ainda assombra nossos dias e ameaça nossa incipiente democracia. Carregamos, como afirmam Teles e Safatle, a violência, esta que está institucionalizada e com ares de legalidade e reforçada pela impunidade do período de transição, ademais de uma sociedade que não possui a cultura de (re) conhecer sua história. Apesar de toda impunidade e do pacto do esquecimento, uma parcela da sociedade se mantem vigilante e resistente, porém, ainda somos assolados pelo fantasma da ditadura, logo, obtemos as marcas da violência, no corpo e na alma, em outras palavras, do trauma particular vivido, já que "A ausência de imagens das torturas é parte do buraco negro da memória da violência da ditadura", como aponta Márcio Seligmann.

A fim de validar o que chamamos de consolidação da democracia, é que se faz necessário buscar justiça, ainda que o primeiro passo tenha acontecido em 1985, com o relatório Brasil: Nunca Mais. Mesmo após denúncias e com o registro dos nomes de militantes que foram perseguidos, torturados e desaparecidos, injustiças aconteceram, pois a responsabilização do Estado sempre foi e ainda é algo inconcluso. Num segundo momento da história, com a Comissão Especial sobre Mortos e Desaparecidos, algumas famílias puderam receber os atestados de óbitos e indenizações, resolvendo parte dos problemas. Passados alguns anos, com a instauração da Comissão da Verdade, em 2011, o que significou mais um grande passo dado em busca do "direito à memória e à verdade", novos elementos foram agregados ao dossiê que pretendia punir aqueles que violaram os direitos humanos, mas ainda não tiveram os crimes reconhecidos, julgados, criminalizados e punidos. 
Com a instauração das Comissões da Verdade, muitas pessoas que tiveram seus familiares desaparecidos sentiram-se esperançosas ao receber notícias sobre seus mortos, pois ainda que muitos documentos estivessem, e ainda estão, sob o comando militar, a chance de quebrar segredos e silêncios familiares ficou cada vez mais possível de ser alcançada, ainda que permaneça a espera por um pedido oficial de desculpas. Foi nesse contexto de esperança e busca que Liniane Haag Brum, mesmo ciente das barreiras da história, sentiu a necessidade de escrever a história do seu tio e padrinho Cilon Cunha Brum, desaparecido político da Guerrilha do Araguaia. Assim, surgiu o trabalho visceral, como ela mesmo cita, intitulado Antes do Passado: o silêncio que vem do Araguaia, projeto contemplado pela Bolsa FUNARTE de Criação Literária, em 2010.

Também provocada pela história presente, em 2015, Pilla escreve seu livro Volto Semana que vem. Ano em que ganhava corpo a falácia de que o Brasil estava quebrado em decorrência do descontrole dos gastos públicos pelo governo federal. Neste ano, as manifestações contra o Governo Dilma Rousseff, orquestradas pelos neoliberais que haviam sido derrotados nas últimas eleições, ganharam força. Foi então, nesse cenário que apontava para um novo golpe, que ameaçava o Estado Democrático de Direito, em meio a pedidos infames de intervenção militar, além da exposição da misoginia, que Pilla escreveu sua obra, ao recobrar o autoritarismo vivido, assim como também viveu a presidenta Dilma, presa e torturada pelo regime militar, e outra vez enfrentando o autoritarismo. Sobre o golpe de 2016, o professor e pesquisador em direito Gilberto Bercovici, em seu artigo, $O$ golpe do impeachment, elucida:

O processo de impeachment é um processo político, mas depende de sólida fundamentação jurídica. Estamos vivenciando no Brasil o que autores como Paulo Bonavides denominam de 'golpe de Estado institucional', ou seja, o regime mantém as aparências democráticas, mas as instituições mudam em sua essência, promovendo a derrubada da Constituição de 1988 para a implementação das políticas econômicas neoliberais, anunciadas no programa denominado 'Uma ponte para o futuro' pelo grupo ligado ao Vice-Presidente Michel Temer. Não necessitamos de sofismas ou de exercícios retóricos para disfarçar a realidade. Impeachment sem fundamento jurídico nada mais é do que golpe de Estado. Um golpe patrocinado por parcela do Poder Legislativo, o que não lhe confere legitimidade alguma. Não interessa de onde se origina, podendo ser proveniente do Poder Legislativo, de um tribunal, palácio ou quartel, tampouco interessa a denominação que se queira dar, a natureza das coisas não muda: golpe é golpe. (BERCOVICI, 2016, p. 145)

Nota-se que foram os episódios recentes da história brasileira, que fizeram surgir a necessidade de escrever, cinquenta anos depois, sobre cenas de um passado autoritário, com isso, as duas autoras contribuem sobremaneira com o resgate histórico de um período ainda nebuloso na história. De acordo com MORAES: 
o levantamento da literatura de testemunho revela um fato interessante: são raríssimos os livros escritos por mulheres, não obstante a significativa participação feminina na luta armada e as torturas, mortes e desaparecimentos de corpos. Muitas das que sobreviveram à tortura e à prisão são jornalistas, professoras universitárias e intelectuais acostumadas a escrever. (apud VECCHI, 2020, p. 3)

Como uma forma de alertar sobre a possibilidade de destruição do estado democrático, para advertir e fazer (re) lembrar para não deixar que se repitam os mesmos erros do passado, Brum e Pilla, mesmo que partindo de vivências e olhares não exatamente semelhantes, utilizamse da escrita para contar, historicamente, sobre as cicatrizes deixadas em suas vidas.

Rejane Pivetta de Oliveira, em seu texto Experiência Ditatorial e Ficção democrática em Volto Semana que vem, de Maria Pilla, reforça a ideia da necessidade da escrita e divulgação de seu livro,

De fato, a presença da ditadura na produção literária contemporânea faz-se no horizonte de um mal-estar da democracia, em que tendências autoritárias ressurgem como forças recalcadas da nossa história política. Nesses termos, no exame dessa ficção, importa explicitar o que desse passado é rememorado, quais são suas dinâmicas e estruturas de compreensão e de que modo o reconhecimento dos resíduos do passado iluminam os "momentos de perigo". (BENJAMIN, 1992, p. 160 apud PIVETTA, 2020, p. 138)

A obra de Pilla trata do contar de uma vida (da vida da autora) que militou contra a Ditadura Militar brasileira e argentina, e cujas vivências ficaram guardadas por cinco décadas, não foram escritas e expostas de pronto, elas tiveram um tempo de amadurecimento, e se fizeram publicamente inevitáveis, pela urgente ameaça de um projeto neoliberal a desenhar-se no Brasil. Como aponta a pesquisadora Coronel, a obra de Pilla elaborou o passado em assimilação com o momento presente:

A reminiscência de um golpe era evocada pela iminência de outro golpe. De diferentes modos, tratava-se de elaborar criticamente o passado, para que o futuro não fosse a repetição mal processada do que já tinha sido vivido cerca de cinco décadas antes. (CORONEL, 2020, p.197)

A narrativa ficcional de Volto Semana que Vem se dá através de um montante de pequenos escritos sobre momentos que mesclam lembranças da infância, da adolescência, da vida adulta, de como tornou-se uma militante, de amigos, e de momentos da repressão militar. Estes trechos não lineares de memórias possuem um fio condutor, o da escrita afetiva, que liberta a autora do labirinto do trauma, e também almeja, assim como Ariadne, nos alertar e nos fazer sair vivos do labirinto da ultradireita e do monstro do autoritarismo, e encontrar o caminho de volta, vitoriosos como o Teseu. Este fio, além de ser a "salvação" de Pilla, quer nos conduzir ao conhecimento da história, para que do presente e futuro não façamos uma repetição do passado. 
Em suma, é através da escrita que Brum e Pilla elaboram o passado e os seus traumas, saindo vivas do labirinto, e também, através desta escrita literária apresentam aos leitores uma melhor forma para processar, fazer conhecer os autoritarismos e trazer uma reflexão sobre os impasses do nosso tempo.

\section{Fio de Ariadne: para que não se esqueça, para que nunca mais aconteça}

Antes do passado: o silêncio que vem do Araguaia, de Liniane Haag Brum é citado por Eurídice Figueiredo em seu estudo dedicado às reflexões sobre a produção literária com temática referente ao período ditatorial no Brasil, em especial, "como expressão de subjetividade" (FIGUEIREDO, 2017, p. 13). Em A literatura como arquivo da ditadura brasileira (2017), Figueiredo aponta que "Para contar o vivido é preciso reinventar através da ficção (FIGUEIREDO, 2017, p. 44)" assim, apresenta a literatura como uma forma de contar o vivido e as vivências traumáticas herdadas por meio das fendas da ficção.

Liniane não viveu diretamente em seu corpo as marcas do regime militar de 1964, mas de forma subjetiva e, inegavelmente herdada, decidiu refazer o percurso do seu tio e padrinho entrevistando pessoas, buscando arquivos, revirando o baú dos registros familiares, tentando revisitar lugares que ela mesma nunca tinha visitado. "Tio Cilon me acompanhou sempre. Era alto, magro, cabelo preto e liso, repartido ao lado. Tão bonito. Meu padrinho era lindo. Pena que quando eu nasci ele desapareceu" (BRUM, 2012, p. 19).

A sobrinha de Cilon, que cresceu em meio a uma história silenciada pelo medo e insegurança da família, só sabia que o tio havia sumido numa tal Guerrilha do Araguaia. Levou tempo para entender o segredo, que seu tio era um desaparecido político. Com isso, depois de vinte anos motivados pela afetividade, pela maturidade e pelo desejo constante de explicações que a história do Brasil não conta, a jornalista, enfim, decidiu "passar a vida do tio Cilon a limpo", mesmo ciente das barreiras que não conseguiria transpor.

Quando Figueiredo menciona sobre as fendas da ficção, Antes do Passado se torna um exemplo. Ainda que a autora apresente uma escrita fragmentária como Maria Pilla, o que é característico dos textos de teor testemunhal, neste caso, Liniane Haag Brum, que não viveu diretamente o regime ditatorial, recorre ao recurso de compor cartas recheadas de afetividade para a sua avó, mãe de Cilon. A autora se utiliza do caráter ficcional para compor a história que sua pesquisa deixou em aberto, não por incapacidade ou desejo, mas por preencher, de forma possível o impossível, aquilo que nunca foi e, talvez, nunca será contado. Sobre a necessidade 
de Brum preencher as lacunas da história através de seu texto ficcional, Jacques Derrida em seu livro Mal de Arquivo: Uma Impressão Freudiana, pontua:

[...] Não haveria certamente desejo de arquivo sem a finitude radical, sem a possibilidade de um esquecimento que não se limita ao recalcamento. Sobretudo, e eis aí o mais grave, além ou aquém deste simples limite que chamam finitude, não haveria mal de arquivo sem a ameaça desta pulsão de morte, de agressão ou de destruição. Ora, esta ameaça é infinita: ela varre a lógica da finitude e os simples limites factuais, a estética transcendental, ou seja, as condições espaço-temporais da conservação. [...] (DERRIDA, 2001, p.32)

Não existiria Mal de Arquivo se não houvesse uma "possibilidade de esquecimento", da "pulsão de morte, de agressão ou de destruição" (DERRIDA, 2001, p.32). Brum escreve de Antes do Passado, ela busca reconstruir a história de seu tio e padrinho Cilon, que ela não chegou a conhecer, escreve sobre uma época em que não viveu, do passado que acontece no presente, e que se não fosse "arquivado" através desta obra literária iria continuar a interferir em seu futuro. Sendo assim, a obra de Brum possui a estética transcendental apontada por Derrida.

As cartas escritas para a vó Lóia, assinadas carinhosamente por Nani, são um recurso característico dos textos de teor testemunhal, pois tentam de forma gentil minimizar as fendas que a história não conta, e de forma enriquecedora, contribuem para o caráter ficcional da obra. "A ficção é parte intrínseca do ato de narrar, mas a fantasia só surge nas narrativas de valor testemunhal para exprimir as incongruências e as ironias do comportamento autoritário" (FIGUEIREDO, 2017, p. 45). Para além disso, o recurso da ficção possibilita a relação entre o fato real e o fato vivido, criando personagens e revelando verdades que, como pontua Figueiredo, é uma literatura que procura trazer à tona passados violentos e bárbaros (FIGUEIREDO, 2020, p. 4).

Sendo Antes do Passado um livro cujo pano de fundo é a Guerrilha do Araguaia - um dos mais sangrentos episódios do regime civil militar - é impossível não considerá-lo como um arquivo da ditadura brasileira importante para a historiografia literária brasileira, pois além de abarcar um tema político, o faz de forma que contempla as especificidades da escrita literária, com características específicas no campo da linguagem, em especial, com destaque para o notável tom poético utilizado pela narradora/ autora. No campo da memória, Antes do Passado apresenta o elo entre um eu e o outro, entre um nós enquanto família e um nós coletivosociedade. Está relacionado ao que Figueiredo chama de vetores culturais, ou seja, a compreensão e a transmutação de um trauma por meio da experiência estética compartilhada. 
A luta pela falta de liberdade em um sistema repressor gerou, com o passar de alguns anos, a necessidade de muitos familiares em compartilhar a dor e tornar viva a memória brasileira sobre um fato que jamais deverá se repetir. $\mathrm{O}$ fio da memória afetiva em comunhão ao desejo de arquivamento é utilizado na escrita de textos testemunhais, almejando para além da terapia de quem conta, alertar a sociedade quanto os males ainda não superados: "homens e mulheres, a grande maioria muito jovens, foram barbaramente torturados, alguns foram mortos, em nome da democracia, quando o regime era tudo menos democrático" (FIGUEIREDO, 2017, p. 15).

A literatura, em oposição à Lei da Anistia, pretende fazer justiça ao relatar e expor o vivido, mesmo com seus interditos. Talvez este seja também um dos destaques de Antes do Passado, pois mesmo depois de 32 anos de muitas investigações e da tomada de consciência sobre o irremediável, a autora, afilhada e sobrinha do desaparecido político Cilon Cunha Brum, tira a venda e encontra rastros da história do seu tio, arquivando estas memórias, simultaneamente afetivas e do mal, a partir do tempo em que se encontra, e nos resguardando do esquecimento e da denegação, como cita Figueiredo (2017, p. 29) "A denegação é uma dupla negação: afirma que não aconteceu aquilo que efetivamente aconteceu".

Assim como a obra de Brum que fez oposição ao esquecimento promovido pelo período de transição do regime militar para o democrático, Volto semana que vem, de Pilla, também narrou sobre o período ditatorial cumprindo assim, a função da literatura como arquivo da ditadura: "E, mais uma vez, voltam os temas da tortura e do exílio da autora que viveu na França em dois períodos diferentes" (FIGUEIREDO, 2017, p. 98), conforme aponta Figueiredo.

Volto semana que vem título do livro e também de um dos subtítulos, é a resposta de Pilla para seu pai ao sair de casa, no entanto, "Mais de dez anos se passaram até eu voltar àquela cozinha" (PILLA, 2015, p.17). O que ficou deste período de espera de seu pai? Uma lacuna. E é desta lacuna que se estrutura a narrativa fragmentária de Pilla, ela narra suas memórias através da escrita, porém não de uma forma linear, mas sim lacunar, como o intervalo entre a "semana que vem" e os mais de dez anos de espera de sua família.

Esta escrita lacunar fragmentária, é recorrente em literaturas de teor testemunhal. Ao iniciar a leitura de Volto semana que vem percebem-se pequenos fragmentos de histórias vivências e memórias da infância, da adolescência, da fase de militância e de sua prisão, todas estas escritas com início meio e fim bem demarcados, e ao decorrer da leitura surge o questionamento de qual estrutura é feita o texto, um romance ou um livro de contos? Enfim, a ultrapassada categorização literária tentando instaurar-se em nossas leituras. Em algumas 
entrevistas, Pilla chega a comentar que seu livro não é muito bom, com um tom quase beirando um pedido de desculpas. Em entrevista ao Sul21 ela conta sobre seu processo de escrita:

Sul21- A opção por histórias curtas foi consciente?

MRP - Elas saíram assim. Eu não sei escrever texto longo.

Sul 21 - Como vês o teu livro como criação literária?

MRP - Alguma coisa eu criei, não tinha o foco na história. Quero continuar escrevendo. Gosto de escrever, de ler, de conversar sobre essa coisa da criação ${ }^{3}$.

Essa visão crítica sobre o processo de escrita nos faz recordar o Primo Levi em seu livro seminal É isto um homem? no qual ele, em seu prefácio, pede desculpas pelos defeitos de seu livro, como observa-se: "Sou consciente dos defeitos estruturais do livro e peço desculpas por eles. Senão de fato, pelo menos como intenção e concepção, o livro já nasceu nos dias do Campo" (LEVI,1988, p. 13). Na verdade, estes defeitos estruturais apontados por Levi, não são uma falha, mas sim uma das características da literatura de teor testemunhal: a fragmentação, também presente na obra de Pilla, e na obra de Brum.

Ainda em comparação entre a obra de Pilla e Levi sobre o traço fragmentário, este, em seu prefácio, justifica o caráter fragmentário do texto: "Daí seu caráter fragmentário: seus capítulos foram escritos não em sucessão lógica, mas por ordem de urgência. O trabalho de ligação e fusão foi planejado posteriormente (LEVI,1988, p. 8)." Tanto em Volto Semana que Vem e É isto um homem? a fusão e planejamento do texto foi deixado em segundo plano, pois o primordial em Levi era contar a urgência dos fatos, e em Pilla, sua memória afetiva. E tal fragmentação é inerente nos textos de teor testemunhal:

O discurso testemunhal é analisado neste contexto como tendo a literalização e a fragmentação como as suas características centrais (e apenas à primeira vista incompatíveis). Ele é ainda marcado por uma tensão entre oralidade e escrita. A literalização consiste na incapacidade de traduzir o vivido em imagens ou metáforas. A fragmentação de certo modo também literaliza a psique cindida do traumatizado e a apresenta ao leitor. A incapacidade de incorporar em uma cadeia contínua as imagens "vivas", "exatas" também marca a memória dos traumatizados. A tradução desses "nós" de memória desses momentos encapsulados ou enterrados em uma cripta (Abraham e Torok) é o objetivo da terapia. O testemunho também é de certo modo uma tentativa de reunir os fragmentos do "passado" (que não passa) dando um nexo e contexto aos mesmos.” (SILVA, 2003, p.2)

Logo, o livro de Pilla possui um caráter fragmentário justamente porque foi contadonarrado na sucessão de suas memórias traumáticas, do que passou individualmente, e também do que ocorreu com os que a cercavam, no seu relato da convivência- sobrevivência em tempos de repressão. Assim, narrar os fatos vividos é narrar suas memórias, e somente quem vivenciou,

3 Sul21. (Ed) Em Destaque. Entrevista Maria Pilla. Disponível em: https://www.sul21.com.br/emdestaque/2015/11/maria-regina-pilla-relembra-momentos-da-ditadura-e-de-tortura-sem-rancor-ou-truculencia/.

Acesso em: 15 nov. 2015. 
no caso de Pilla, o regime ditatorial é que pode, na condição de sobrevivente, colocar seu testemunho e suas memórias por escrito.

Além de uma narrativa fragmentada, contada de acordo com a necessidade da memória traumática, e não por uma ordem cronológica, como vimos ser característica da literatura de teor testemunhal. Outra necessidade soma-se à narrativa não-linear de Pilla, que é a de contar aos outros e os tornar participantes dos acontecimentos ocorridos nos períodos ditatoriais, com a intenção de que tamanha violência não mais se repita, o que caracteriza como relato de uma perspectiva coletiva. Ademais da necessidade coletiva, também se faz presente a perspectiva privada, na direção de sentir alívio, ao conseguir expor, mesmo que de forma metafórica, as vivências e memórias da prisão, da tortura e do exílio.

Sobre as memórias coletivas e privadas, Pilla em seu livro diz que "Essa dor tão íntima e tão pública não se divide com qualquer um" (PILLA, 2015, p. 13), no entanto, ela a divide com seus leitores. Essa necessidade do sobrevivente em compartilhar com o coletivo uma dor íntima - privada surge, como afirma Michael Pollak, da convergência de razões políticas e familiares que concorrem para romper esse silêncio: "no momento em que as testemunhas oculares sabem que vão desaparecer em breve, elas querem inscrever suas lembranças contra o esquecimento" (POLLACK, 1989, p. 6-7). Logo, as instâncias entre o privado e coletivo se misturam, pois as memórias dos sobreviventes, a memória de Pilla nos conta e nos faz refletir sobre a história de uma comunidade, da nossa história. Ainda com Pollak para elucidar a questão da memória privada que se faz coletiva: "há uma permanente interação entre o vivido e o aprendido, o vivido e o transmitido. E essas constatações se aplicam a toda forma de memória, individual e coletiva, familiar, nacional e de pequenos grupos." (POLLACK, 1989, p. 9).

Como aponta Seligmann Silva em seu texto "Testemunho da Shoah e literatura", tanto a perspectiva coletiva como a privada, são duas necessidades presentes na escrita de teor testemunhal. A primeira como arquivamento, em um sentido de alerta para as gerações que não viveram a ditadura, para que conheçam o seu passado, e assim possam evitar atrocidades similares no presente e no futuro, e a segunda como ato de escritura, para a liberação interior.

Estas duas perspectivas se notam durante todo texto de Levi, assim como no de Pilla. Ressaltamos que em Volto Semana que vem, Pilla nos faz participar do ocorrido, não de forma brutal e violenta como característico do período ditatorial, mas sim através de uma narrativa leve e afetiva. A escritora nos faz um alerta para que não deixemos mais atrocidades como as do passado, ocorrerem novamente. Estes relatos de vivências em muitas vezes são narradas em primeira pessoa do plural, como um testemunho coletivo (um eu com ressonância coletiva, um 
eu que nos adverte sobre o que passaram) e em outras vezes, Pilla utiliza a primeira pessoa do singular (um eu que conta do seu "privado" o que sentiu, e como tornou-se uma sobrevivente para poder nos contar essa história, e o contar desta história é sentida como mais uma forma de libertação e alívio). No subtítulo "Prisão de Villa Devoto, Buenos Aires" temos exemplos desta focalização do "eu" por "nós":

O Grande Gatsby não é um grande filme, mas foi minha última ida ao cinema antes da detenção. Todo fim de semana tínhamos sessão de cinema, e no sábado seguinte $e u$ contaria esse filme. Já tínhamos escutado vários. Profundo di donna era o meu favorito; falava muito em dores, nossa grande carência naquele lugar. Éramos catorze num espaço retangular com beliches. Uruguaias, Argentinas e eu. As "sessões" eram o que podíamos fazer de menos dispendioso para sair daquele lugar. Na cela, o calor sufocava. (PILLA, 2015, p. 10, grifo nosso)

Essa narrativa individual que se faz coletiva, apesar de apresentar uma sucessão de memórias traumáticas ocasionadas pela ditadura, transcorre com leveza e ternura, como já mencionado, utilizando-se da linguagem poética com a presença de metáforas e sinestesias, como pode-se observar no trecho abaixo referente ao subtítulo "A Gatinha do Edredom":

\begin{abstract}
Aterrorizada pelo silêncio e pelo capuz, não me mexi, continuei quieta no meu canto. Trim trim trim! insistia o telefone. Virei-me debaixo do edredom e lá estavam os olhos arregalados da gatinha - como sempre fazia -, esperando minha reação. Engano, número errado, respondeu a voz. Quis abraçar o corpo quente e macio do animalzinho. Era só um pesadelo, repetia, contente da vida. Senti uma fisgada aguda no pé e levantei o edredom, agora muito sujo e com cheiro de urina. Debaixo dele, em vez da gatinha, vi meus pés manchados de sangue e estrangulados pela corda. $O$ cheiro: inesquecivel cheiro de roupa suja misturado a um vago odor de pele queimada pelos fios desencapados (PILLA, 2015, p.30-31, grifo nosso).
\end{abstract}

Nota-se a narrativa poética da escritora com tons de leveza e certa alegria, porém estes recursos estilísticos não são utilizados com a intenção de minimizar os horrores das ditaduras brasileira e ou argentina, mas sim para acercar - se dos seus traumas e poder comunicá-los. Pollak em seu texto Memória, Esquecimento, Silêncio (POLLACK, 1989, p. 9) relata que muitos sobreviventes ao darem seu testemunho "não os relatam com datas", números ou com dados que são "publicados diversas vezes", mas sim através de diferentes ordens sensoriais, como é o caso de Pilla, que cria efeitos sinestésicos, como evidencia-se na citação acima, mais especificamente nas partes grifadas. Ainda que por meio de uma escrita leve, Pilla, em seu texto testemunhal, preserva o diálogo entre história e literatura contando fatos que não estão nos livros e ratificando seu compromisso em preservar a memória coletiva, mas sem romper com o campo literário.

Em Antes do Passado, também há a presença de uma escrita poética com tons de leveza para contar um dos mais violentos episódios da ditadura brasileira: a Guerrilha do Araguaia. 
Porém, diferentemente de Volto semana que vem, que é contado pelo sobrevivente, Antes do Passado é narrado pela voz que, num ato de "cerzir o passado", assume responsabilidade política na e com a sociedade a fim de elucidar, ou pelo menos tentar entender as fendas deixadas pela história. Desta forma, é possível apontar nesta obra o que alguns críticos conceituam como pós-memória, que, segundo Marianne Hirsh (2014), “descreve a relação que a 'geração seguinte' mantém com o trauma cultural, coletivo e pessoal vivido por aqueles que a precederam". Como nas histórias de outros desaparecidos do regime, a família, através de Liniane buscou os rastros de Cilon Cunha Brum num ato conscientemente póstumo, assim:

a pós-memória, explicita de maneira muito mais acentuada o caráter político de memória, talvez por sua própria origem, geralmente identificado ao Holocausto ou a narrativas de cunho social que incorrem em uma postura de testemunho de gerações que atrasam sua herança ou mesmo a negam. (CARMO, 2015, p. 175)

A sobrinha e jornalista não venda os olhos em relação a história que, mesmo não sendo vivenciada pelo seu corpo, marcou sua alma, sua trajetória, sua família e toda sociedade. Através desta obra, Brum colabora com a elaboração do trauma particular e coletivo que a ditadura provocou e ainda emana na sociedade, mas é especialmente pela afetividade, que Liniane sempre buscou, ousou e, ao mesmo tempo, se questionou sobre todos os estilhaços de memória que recebia:

Enquanto isso, a emoção me traía, soprava ao ouvido que não devia confiar no homem. Em seguida, ralhava comigo - por que desconfiar de alguém que abre a casa a uma desconhecida? A razão mandava que me conformasse com qualquer estilhaço de memória que nele estivesse meu tio - e o instinto alertava que o herói da minha história merecia lugar de destaque. Nada de Oswaldo, Simão agora era o rei. (BRUM, 2015, p.175)

Liniane Haag Brum e sua obra, pertencem "a segunda geração que consegue ressignificar as histórias herdadas" (ASSUNÇÃO, 2020, p. 231), pela escrita. Numa tentativa de reconciliação, a autora-narradora busca entender e perdoar aquilo que não viveu, mas herdou. Depois de todo seu trabalho de investigação, entre pesquisas arquivadas e entrevistas, Brum elabora em Antes do passado o seu acerto de contas com o passado traumático e, mais uma vez, por meio da escrita afetiva e ficcional se direciona a vó Lóia, pessoa da qual a narradora se responsabilizou desde o início a enviar notícias sobre a busca do tio, assim, fechando um ciclo consigo e com o coletivo:

Não, vozinha, não é que eu esteja te abandonando - como poderia deixar para trás o que faz parte de mim? Seria como morrer um pouco. Seria deixar de ser. E, vó, sinceramente, esse espaço tão nosso que foge até mesmo da minha compreensão esse tempo antes do passado, vozinha, vai ser sempre o lugar do tio Cilon. O recanto dele, íntegro e inteiro. Um lar onde passamos a limpo sua vida e feições. Nosso canto de polir palavras com panos plácidos e puros. E ponto. (BRUM, 2012, p.260) 
Para além dos distanciamentos que diferem Antes do passado e Volto semana que vem em textos testemunhais de pós memória e memória é importante salientar um ponto comum entre os protagonistas dos dois romances. Um aspecto notável na geração em que viveu e resistiu na luta pela democracia: a consciência das escolhas feitas. É possível concluir pelas narrativas que tanto Cilon Brum como Maria Pilla nunca foram inocentes em seus atos, ambos sabiam muito bem dos riscos que corriam em ousar a lutar contra um sistema repressor. Nunca foi falta de opção ou imposição:

Tio Cilon não agiu sem pensar. Ele planejou e acreditou no que estava fazendo. A senhora sempre disse que seu filho tinha personalidade muito forte pra ser levado. Não foi levado. Escolheu. (BRUM, 2012, p. 107)

No final de 1971, foi pela rota chilena que entrei na Argentina. Menos arriscado. Certamente um caminho mais longo e uma marcha à ré na história: saía de um país com um governo civil recém-eleito para outro em plena ditadura (PILLA, 2015, p. 13) "Ué, guria, pra onde tu vai? O pai vestia um pijama claro, estava em pé na cozinha. Eu deveria sair por uns dias. Quis exagerar para não assustar, se demorasse, mais que o previsto (PILLA, 2015, p. 16)

As citações acima reforçam que tanto Cilon, quanto Pilla, não foram vítimas do sistema opressor, mas sim foram combatentes desse sistema. Lutaram conscientemente contra o regime militar. Cilon no Araguaia e Pilla, tanto no Brasil, como na Argentina.

Ambas narrativas expressam em suas tessituras que a escrita afetiva de quem viveu o trauma como Pilla ou quem o herdou, como Liniane, tratam de mostrar a coragem e a ousadia dos protagonistas destas histórias, pois mesmo sendo pessoas em situações financeiras privilegiadas, que tinham acesso ao ensino superior, Cilon e Pilla acreditavam na promoção da igualdade e na democracia.

\section{Labirinto percorrido, porém atentos e fortes}

A Lei da Anistia no Brasil corroborou para sermos um país do esquecimento, e a literatura, sobretudo as obras atuais, trabalha para reativar a memória dos anos de chumbo, fazendo dos textos literários arquivos da ditadura. Somos herdeiros da impunidade deixada pelo processo de redemocratização do país. Nossa ainda jovem democracia é frágil, pois o poder não emana do povo, como deveria, logo, vivemos em um país de brutal desigualdade social, em que o poder vem e serve ao capital.

Desde a implementação da democracia, tivemos diversos projetos políticos democraticamente eleitos, uns em benefício aos empresários, e outros às camadas populares. Desde o ano 2003, vigorava consecutivamente na presidência o Partido dos Trabalhadores que tinha como projeto político fortalecer o Estado e atender as urgências da população. Em 2014 
ocorreu a reeleição da Presidenta Dilma Rousseff que daria continuidade à gestão do Partido dos Trabalhadores na presidência, porém, no mesmo ano se deu início a uma sistemática sabotagem de seu governo.

Tal sistemática iniciou com o pedido da recontagem dos votos solicitada pelo PSDB e demais partidos da direita que após sucessivas derrotas não aceitaram o resultado democrático das urnas, seguida de pedido de impeachment logo no terceiro mês de gestão Dilma. E assim teve início a construção do golpe, com apoio do Congresso, da mídia, de segmentos do judiciário e do mercado financeiro. Os quatro pilares orquestradores do golpe comungavam dos mesmos interesses dos derrotados, e juntos, orquestraram a inviabilidade do governo. Como aponta, sobre a conjuntura do golpe, João Ricardo W. Dornelles e Carol Proner no texto: Breves reflexões sobre a conjuntura do golpe: Desafios para a esquerda brasileira,

[...] as razões para a interrupção brusca do governo foram ganhando corpo pela própria
vocação dos partidos de oposição de corte neoliberal (PSDB, DEM) sustentados pelas
classes médias tradicionais e pela elite, suscetíveis aos apelo de lobistas das petroleiras
internacionais e da mídia oligopolista privada. O elemento surpresa revelado nos
últimos tempos é o papel de setores expressivos do poder judiciário, cada vez mais
conservadores e adaptados aos interesses econômicos da elite e criando uma
conveniente simbiose entre mundo jurídico e mundo político, conveniente porque
fornece um envelope pseudo-legalista ao golpe. (DORNELLES e PRONER, 2016, p.
186)

No tocante à conjuntura que levou para a preparação do golpe, é necessário avaliar o ano de 2015, que com a grave crise política, ocasionada pelos grupos de oposição que não aceitaram a escolha democrática das urnas, conduziram o Brasil para um estado de recessão, e assim ganharam força as manifestações com pedidos de impeachment da presidenta, além de pedidos de intervenção militar.

Com o golpe em curso, e também após a instauração da Comissão Verdade, reativaramse os resíduos das memórias do golpe de 1964. A atmosfera de ameaça ao regime democrático de direito fez surgir em algumas obras literárias atuais a necessidade de reiterar que tivemos sim um golpe civil-militar, e que foi um longo período de liberdades cerceadas, de violências, de mortes e de torturas. Logo, as obras literárias com a temática do regime totalitário insurgem "para que não se esqueça, para que nunca mais aconteça", em conformidade ao lema da Comissão Nacional da Verdade.

Para além de um lugar da memória, a literatura segue mostrando seu caráter de denúncia, resistência (ao esquecimento) e empatia com as dores alheias. Terreno onde dialogam os discursos e vestígios do passado, o texto literário aparece, assim, como o campo simbólico que propôs desfazer as mínimas dobras do passado lá onde teimavam ocultá-lo ou apagá-lo. (ASSUNÇÃO, 2020, p. 237) 
Tanto o livro de Liniane Haag Brum, como o de Maria Pilla, são obras de teor testemunhal (a primeira herdeira da ditadura, e a segunda, sobrevivente da ditadura), onde ambas relatam, por meio da escrita literária, sobre as catástrofes sociopolíticas ocorridas no Brasil durante o século XX. As duas autoras, através do fio da escrita, salvam-se do labirinto do trauma e reforçam a resistência contra o esquecimento, pois a escrita com teor testemunhal, utilizando-se da linguagem literária, possibilita o encontro impossível entre o "real" e o "simbólico", entre o "passado" e o "presente". Sendo assim, a literatura de teor testemunhal atua como um fio condutor para fazer-se possível no discurso fragmentado das memórias traumáticas, tornando-as verossímeis.

\section{Referências}

ASSUNÇÃO, Sandra. Em nome dos pais, de Matheus Leitão: um relato (pós)memorial contra o esquecimento. In: GOMES, Gínia Maria (org). Narrativas brasileiras contemporâneas Memórias da Repressão. Porto Alegre: Polifonia, 2020, p.211-239.

CARMO, Claudio do. Da memória à pós-memória: ilações políticas e a ficção literária contemporânea. In: Cerrados, v. 24, n 40. Revista do Programa de Pós-Graduação em Literatura, UNB. $\quad$ p. 173-185, $2015 . \quad$ Disponível em: https://periodicos.unb.br/index.php/cerrados/issue/view/1783/v.\%2024\%2C\%20n.\%2040 $\% 20 \% 282015 \% 29$. Acesso em: 12 dez. 2020.

CORONEL, Luciana. Reminiscências de uma vida individual eivada de anseios coletivos: Volto semana que vem, de Maria Pilla. In: GOMES, Gínia Maria (org). Narrativas brasileiras contemporâneas - Memórias da Repressão. Porto Alegre: Polifonia, 2020, p. 195210.

DERRIDA, Jacques. Mal de Arquivo: uma impressão freudiana. Rio de Janeiro: Relume Dumará, 2001.

FIGUEIREDO, C. A.S., \& DA SILVA SANTOS. Literatura do testemunho no Brasil. Revista EntreLetras, Araguaína, v.11, n.2, p.300-316, 2020. Disponível em: https://doi.org/10.20873/uft.2179-3948.2020v11n2p322. Acesso em: 20 abril 2021.

FIGUEIREDO, Eurídice. A literatura como arquivo da ditadura brasileira. 1. ed. Rio de Janeiro: 7 Letras, 2017.

HIRSH, Marianne. (2014). Connective histories in vulnerable times. PMLA, v. 129, n.3, May, p. 330 - 348. Disponível em: https //bit.ly / 3e04geh. Acesso em: 20 mar.2020.

PIVETTA, Rejane; PAULO, Thomaz. Literatura e ditadura. $1^{\circ}$ ed. Porto Alegre: Editora Zouk, 2020. 
POLLACK, Michael. Memória, esquecimento e silêncio. Rio de Janeiro: Estudos históricos, 1989.

PRONER, Carol; CITTADINO, Gisele; TENENBAUM, Márcio; FILHO, Wilson Ramos (orgs). A resistência ao golpe de 2016. Bauru: Canal 6, 2016.

SILVA, Márcio Seligmann. Imagens precárias: inscrições tênues de violência ditatorial no Brasil. In: Estudos de literatura brasileira contemporânea, n.43, p. 13-34, jan./ jun.2014.

SILVA, Márcio Seligmann (org). História, Memória, Literatura. O testemunho na era das catástrofes. Campinas: Editora da UNICAMP, 2003.

TELES, Edson; SAFATLE, Vladimir (org.). O que resta da ditadura: a exceção brasileira. São Paulo: Boitempo, 2010. (Estado de sítio).

VECCHI, Roberto; DI EUGENIO, Alessia. A dupla cicatriz: a ditadura brasileira e a vocalização feminina da memória traumática de Ana Maria Machado. Estudos de literatura brasileira contemporânea, Brasília, n. 60, e 6009, 2020, p. 1-10. 